\title{
'THE HASTENING THAT WAITS': A CRITICAL ASSESSMENT OF THE TANGEBILITY OF UNITY WITHIN THE UNITING REFORMED CHURCH IN SOUTHERn Africa
}

\author{
Authors: \\ Rothney S. Tshaka ${ }^{1}$ \\ Peter M. Maruping ${ }^{2}$
}

\section{Affiliations:}

${ }^{1}$ Department of Philosophy and Systematic Theology,

University of South Africa,

South Africa

${ }^{2}$ Department of Church History, Missiology and Christian Spirituality, University of South Africa

Correspondence to: Rothney Tshaka

email:

tshakrs@unisa.ac.za

Postal address:

Department of Philosophy and Systematic Theology, PO Box 392, UNISA 0003, South Africa

\section{Keywords:}

tangible unity; justice; reconciliation; URCSA;

Reformed Church

Dates:

Received: 17 Aug. 2010

Accepted: 27 Oct. 2010

Published: 07 Dec. 2010

How to cite this article: Tshaka, R.S. \& Maruping, P.M, 2010, 'The hastenings that waits': A critical assessment of the tangebility of unity within the Uniting Reformed Church in Southern Africa', Verbum et Ecclesia 31(1), Art. \#426, 4 pages. DOI: $10.4102 /$ ve.v31i1.426

\section{This article is available} at: http://www.ve.org.za (c) 2010. The Authors. Licensee: OpenJournals Publishing. This work is licensed under the Creative Commons Attribution License.

\begin{abstract}
The tale of the Reformed Church tradition in South Africa remains conspicuous with challenges also within the current democratic context. Whilst the political past of South Africa contributed towards a Reformed church divided along racial lines, a struggle continues for a genuinely unified Reformed church today. Conceding to the present discussions about the possibility of uniting all Reformed congregations that were divided along racial categories of Black, Coloured, Indian and White, this article aspires to delve into the intricacies pertaining to the already achieved unity between the 'Coloured' and a huge portion of the 'Black' Reformed congregations, that is to say, the Uniting Reformed Church in Southern Africa. This article will argue that although it is fundamental that the church of Christ must be united, it is equally imperative that the Uniting Reformed Church in Southern Africa (URCSA) waits and assesses whether it has already achieved tangible unity.
\end{abstract}

\section{INTRODUCTION}

The 'hastening that waits' is a theme which is taken from the exquisite work of Nigel Biggar (1995) in which he attempts to do justice to the ethical thought of Karl Barth. In this work he illustrates Barth's notion of right human action as that which is able to hasten in the service of humanity in particular by waiting prayerfully upon God; it also highlights Barth's distinguished openness to moral wisdom outside the realm of the Christian church.

Biggar is convinced that the ethical thought of Barth had been grossly overlooked by ethicists until relatively lately in the English-speaking world simply because the manner in which Barth deals with the issue in question raises much discomfort. The reason why Barth's ethics raises discomfort is because of his emphasis on the divine and its relation to the human activity (see Biggar 1995, introduction).

Barth is known to be a devout challenger of systems and it is for this reason that Biggar (1995) reminds us of Barth's definition of a system which for him is 'a structure of principles and their consequences, founded on the presupposition of a basic view of things ... self contained and complete in itself'. Seen in this way, if God's will is identified in an ethical system with a particular 'basic view', with a fundamental idea or principle, 'it [God's will] is brought under human control'(Biggar 1995:11).

Ethics and systematic ethics per se therefore pose a problem for Barth and his view of the essence of ethics. It is for this reason that Biggar discusses the difficulty that Barth has with systematic ethics under his rubric ethics as hearing aid.

The current period in the life of the Reformed Church in South Africa is a tumultuous period because talks concerning the reunification of this church have vacillated from 'promising' to 'discouraging' with the change in the leadership of the Dutch Reformed Church. At some point there was much excitement about the possibility of unity with DRC daughter churches. ${ }^{1}$ However, this excitement needs to be weighed against the unification of the Dutch Reformed Mission Church (DRMC) and a huge section of the Dutch Reformed Church in Africa (DRCA) to form the Uniting Reformed Church in Southern Africa (URCSA).

This article will argue that although it is imperative for the divided Reformed Church to unite, it has become necessary to explore to which extent the already achieved unity which produced the URCSA encourages a process of reunification with the broader South African Reformed Church. With numerous discussions about unity, this article will rely (to a large extent) on talks relating to the mentioned subject. This article is a humble and simple attempt to galvanise an earnest debate about the subject of unity within the URCSA.

\section{THE IMPORTANCE OF UNITY FOR THE UNITING REFORMED CHURCH IN SOUTHERN AFRICA TODAY}

One of the fundamental issues within Reformed Church governance and politics is the issue of unity. The creeds and confessions of the Christian church have always endeavoured to emphasise the importance of unity. When Barth made the claim that God reveals himself in his 'three-in-oneness' (cf. Barth 1956:406f), he was clearly in congruence with the many Reformed Christian leaders who

1.The Reformed Church in South Africa here refers to all the Reformed Churches which have their origin in the Dutch Reformed Church. These are the churches that were independently established because of the politics of race and apartheid in South Africa; viz. Dutch Reformed Mission Church - Coloured; Dutch Reformed Church in Africa - African; Dutch Reformed Church - White' and the Reformed Church in Africa - Indian. 
preceded him. This revelation (to which Barth was alluding to) was to consolidate the inevitability of unity in a Godhead that wishes the same for his church.

The unity of the church is one of the most fundamental aspects of the Church because it addresses the critical distinction between the 'false' and the 'true' church. However, at the same time, it needs to be said that the unity envisaged by the Reformed Christians and the one to which Barth refers in his usage of the revealedness of God in his trinity, had nothing to do with a perception of a unity that opposes differences.

Concerning the position of the URCSA, it must be admitted that the Belhar Confession represented a watershed in its history. ${ }^{2}$ One of the reasons why this new united church deliberately decided not to include the word Nederduitse-(Dutch) as it deliberated on its new name, was to indicate the progress of its theology in a new context. Nonetheless, it must also be conceded that the URCSA (which is the combination of the DRMC as well as a huge portion the DRCA) has its origin within the Dutch Reformed Church (DRC). It is to be expected that in the Confession of Belhar (as is the case within the Reformed church tradition) that unity is one of the fundamental issues adjacent to reconciliation and justice.(cf. Smit 1984:53). The exclusive emphasis on unity in the recent discussions between the DRC and the URC creates a problem regarding the other issues that the Belhar confession calls for. There is always the perception that unity is alleviated above reconciliation and justice. But, in fact, it must be realised that the Belhar Confession calls for justice, unity and reconciliation, all at the same time.

It is also true that the theology which gave theological structure to the Belhar Confession was to a large extent extrapolated from the response of the confessing church in Germany in response to Hitler's Nazism and the German Christians. When Barth was asked (fairly ahead of the adoption of the Barmen Declaration of 1934) to respond to the question of the need and possibility of a universal reformed confession, he responded with an explication that can easily be considered to be his best exposition of what and how a Reformed confession can be constituted and understood. He argued that:

A reformed creed is the statement, spontaneously and publicly formulated by a Christian community within a geographically limited area, which, until further action, defines its character to outsiders; and which, until further action, gives guidance for its own doctrine and life; it is a formulation of the insight currently given to the whole Christian Church by the revelation of God in Jesus Christ by the holy scriptures alone.

(Barth 1962:112)

From this explanation it is clear that although a confession is basic to the Reformed church tradition, it remains merely a commentary on the Word of God and is not the Word of God per se. In Barth's view a confession is not meant to be something that remains in its original form for eternity. Where this happens, it can only be due to the fact that the confessors were not faithful to the Reformed church tradition of admitting that their 'Yes' might become a 'No' tomorrow.

There is a tendency amongst South African theologians to compare the Belhar Confession indiscriminately with the Barmen Theological Declaration (cf. Horn 1984). Although it remains clear that a Status Confessionis was applied in both cases and that both cases where confronted with an awkward position of confessing Christ against those who have assumed his position, it should be emphasised that the contexts were different. The subject of unity, which is in question here, was

2.The history of this church has been recited tirelessly. To fully comprehend the history of the URCSA it is fundamental that the history that precipitated the Black and Coloured sections of the DRC be consulted. Many have written extensively on this coloured sections of subject, therefore attempts of relterating this history here wilnot assist the objective sections of this church see Loff 1998 . For a detailed discussion of the history of this confession, cf. amongst others, Smit and Cloete (1984). not as important as it was with Belhar (and as it continues to be today). The Barmen Declaration did not call for churches to unite - although it could be argued that this call was implied. The synod that produced Barmen comprised more than one denomination, that is to say, United, Lutheran and Reformed.

Let us also be reminded that the Bekennende Kirche was blamed for selfishness because it did not in essence oppose Hitler and his ideologies but was against the fact that the state was dictating ways in which the church should conduct its business. George Harinck (2003:9) asserts that: 'de Bekennende Kirche was alles behalve anti-national-socialistisch'.

The difference between Barmen and Belhar was that at the meetings of the former, members who were both opposed and in favour of Hitler's policies were involved in the deliberations that led to a public declaration against the intervention of the state in the affairs of the church. The situation in Belhar was different in the sense that it was a congregation of those who became convinced at a particular time that apartheid was in essence a heresy and stood in contradiction with the Christian gospel.

In addition, we should state that some DRC congregations have accepted the Belhar Confession and have been working together with URCSA congregations. It is our view that one is not overstating the point when one says that the question of unity remains a controversial question within the Reformed church family in South Africa.

Smit (2000) is correct in arguing that,

church unity is not simply a well-sounding slogan that can be easily bandied about. On the way to effective unity the pain of unrighteousness will be exposed in a thousand ways.

(Smit 2000:55)

Here, Smit is quite aware of the fact that church unity will have to take into account the discrepancies in the socio-economic and political facets that were brought about by the apartheid system. In this way, it can be said that Smit recognises that unity can only be genuine if it takes seriously the issues of justice and reconciliation amongst the people of South Africa. Unfortunately in that study Smit does not leave us with a clear impression of how this unity might look like once it is realised.

We conclude nonetheless that with regard to the issue at hand, reconciliation and unity should not be a cheap reserve simply because one group wants to appeal to the other. It should not be as is understood by some members of the DRC that reconciliation which is intrinsic to unity is best understood to simply mean having good relationships with people across the political boundaries (Smit 2000:162)

\section{‘THE HASTENING THAT WAITS': HOW TANGIBLE IS UNITY WITHIN THE THE UNITING REFORMED CHURCH IN SOUTHERN AFRICA?}

The title of this article gives us a glimpse of Barth's real visualisation of the Kingdom of God (cf. Biggar 1985). Barth (1981) acknowledges that for those who earnestly pray this prayer,

the petition 'thou Kingdom come' cannot mean that they are permitted to be idle for the time being; to acquiesce for the time being in human unrighteousness and disorder.... Instead they wait and hasten toward the dawn of God's day, the appearing of his righteousness. They not only wait but also hasten. They wait by hastening

(Barth 1981:263)

In a very real sense this article appreciates the gravity and urgency of the URCSA to be involved in a process of waiting and 
hastening towards the unity of the church in present day South Africa. Church unity is not only a thorny issue in conversations between the DRC and the URCSA, but remains a thorny issue for the URCSA itself. Although the URCSA remains very zealous about unity essentially because it is convinced that this is one of the cardinal objectives to which the church must strive for, it is not yet clear as to what type of unity is envisaged. ${ }^{3}$ It should be stated that although it is a fact that unity has somewhat been achieved structurally, it has found to be wanting when it comes to unity between Black and Coloured people on the grass roots level. ${ }^{4}$

Evidently the division between Black and Coloured people was a cunning and shrewd political manoeuvre which was facilitated by the apartheid ideology. It is always taken for granted that because apartheid discriminated in essence against those who were not classified as being of European descent, that it is irrelevant to speak about differences between those who were on the receiving end of this ideology. It is our contention that it would be naïve to assume that the URCSA is not plagued with its own difficulties. The appeal won by the Dutch Reformed church in Africa against the verdict that it has ceased to be an independent church and that it has been incorporated into the URCSA has challenged the relationships that exist between Black and Coloured people.

After winning the case, many DRCA members (especially in the Phororo ${ }^{5}$ and Free State synods) threatened members of the URCSA with violence if they would not vacate the buildings that they claimed to be the property of the DRCA. Many Black ministers felt disappointed by their Coloured colleagues who did not seem to empathise with them when faced with such incredible threats. There are still a number of court cases pending in Mafikeng and Kimberley districts.

Whilst not many are willing to concede to these differences within the URCSA, let alone discuss them, the socio-economic, cultural and even political differences have and will continue to have definite implications for tangible unity in the URCSA and definitely for a United Reformed Church. For unity to be tangible, it is imperative that unity be established not only at structural levels but at grassroots levels as well. The fact that the DRCA (with some exceptions) was able to unite with the DRMC is a well-known fact, even though the difference of opinions, which prevailed during the unification processes, were not dealt with adequately. Chris Loff (1998:273) reminds us of the internal resistance against church unity within the early URCSA, but does not explicate the reasons for that resistance. It is clear that

3.In the many conferences and workshops between the DRC and the URCSA which we attended it became clear to us that the URCSA has no major reservation which might impede on the reunification of the Reformed Church in South Africa. We believe that this church remains more than ever enthusiastic about reuniting with the broader Reformed Church. Suffice it to say that the segregated history of South Africa divided Black people from White people and furthermore divided Black people into categories of Black, Coloured and Indian. It is the contention of this artict the into categories of Black, Coloured and Indian. It is the contention of this article that the Colour between the DRC and the former Dutch Reformed Mission Church - in other words, a history between whites and Coloured of the Reformed Church tradition in South Africa. It is also noted that a credible account of the African section of the Reformed Church is not forthcoming whilst the remaining African faction which insists on the independent existence of the Dutch Reformed Church in Africa claims ownership of the history of African people in the Reformed Church. A responsibility is thus bequeathed to African Christians within the URCSA to ascertain that an African perspective of the history of this church is not overshadowed by the dominant accounts of the Coloured and White reformed Christians. See, R.S. Tshaka (2007:533-548).

4. The geopolitical context of the URCSA continues to strain a process of true unity because each one attends a church in the vicinity where one resides. When this is taken into consideration one is left with the view that the Federal model of unity which is heavily advocated for by the DRCA and some DRC congregations seems more realistic at this point than a unity which transcends language, culture and social settings as advocated by the most of us. The leadership of the URCSA opposes a Federal model of unity because it remains of the view that it directly and indirectly encourages a church adhering to such a view to be the protector and custodian of a particular culture, language and sentiments.

5'Phororo' is a Sesotho word which means 'streams of water'. This name is given to the Synod that is located in the Northern Cape Province and extends to some parts of the Free State province. resistance to church unity was a mutual affair. Groups in both sides of the camp were sceptical of unity and perhaps still are today.

Brief reference was made to the geographic locations where Black and Coloured people were traditionally located. Clearly the the Group Areas Act of 1950 (Act No. 41 of 1950) and other facts have structured the geographic boundaries in such a manner that inhibits many from worshipping together. This has also helped in underscoring the view held by some that reconciliation is something, which can be achieved without living near to one another, belonging to the same denomination as well as carrying one another's burdens (cf. Smit 2000:162). In addition, the question of culture and language, which is always thrown in like a cat amongst the pigeons when it comes to unity talks remains a challenging aspect in unification talks.

We are not oblivious to the point that culture and language remain fundamental building blocks also for the reunited Reformed church in South Africa today; however, it would be naïve to consider these two issues as the only impediments of genuine unity. The advent of true unity in the URCSA is held ransom by the fact that there are many aspects that frustrates the process (amongst them of course must be counted the issues of culture and language).

Equally important, however, is the issue relating to the socioeconomic and political situation of present day South Africa. This is a situation whereby a Black congregation is bound to call a Black minister to pastor them and such is the case with Coloured ministers and Coloured congregations; reasons cited for this is sometimes conveniently confused with language and culture, although it remains our view that the reasons for this is more socio-economical and political than it is cultural and linguistic. For one to appreciate this, one has to consider the apartheid history which deliberately created a socio-economic and political wedge between Black and 'Coloured' people in South Africa.

Suffice it to say that if there is consensus on views that ministers can play a pivotal role to effect change on grassroots level, then at least the present church administration and management ought to consider the possibility to equip its ministers to help in transcending these boundaries. It is our view that just as much as justice and reconciliation is needed and remains essential for White and Black people to survive both in church and in society, so is this justice and reconciliation fundamental for the survival of both Black and Coloured people in church (URCSA) as well as in society.

\section{CONCLUSION}

At this point, we must point out that one of the essential aspects in dealing with the problem of unity in the URCSA is that such a dialogue ought to be undertaken with sincerity. There are differences between us as people, yet something ought to be done to take advantage of the beauty of these differences. To the best of our thinking, it is fallacious to assume that the URCSA is constituted only by its top leadership.

Perhaps the URCSA must entertain the possibility that the unity they are aspiring to is not the one that is currently displayed in reality and that because it is unable to assist in narrowing the linguistic, cultural, socio-political gaps created between Coloured and Black people by apartheid, the URCSA should admit that perhaps the Federal model propagated by the DRCA and some DRC congregations has been realised in this church.

When we speak about the URCSA it should be understood that we are primarily referring to those Black and Coloured people who commute on a daily basis to their places of work, those who interact with one another and in their intercourse with one another wrestle with these very questions of unity, reconciliation 
and justice albeit not using the same theological jargon used by theologians. It is about these men and women who have to return every day to their respective homes and once again be confronted with the impossibility of tangible unity. True unity which has at its core genuine justice and reconciliation can only be achieved when those Black and Coloured people who were traditionally estranged from each other are united on grassroots level.

Undoubtedly this has implications for how the URCSA propose what type of church it seeks to be. It seriously questions the rationale behind the monologue that this church has been having with the DRC for quite some time now. With the constant change of the social and political set up of the South African situation, it is perhaps time that we began to accept the possibility that a Reformed Church, secretly yearned for by some who reminisce about the so-called 'good olden days' where the church was to be the custodian of a particular culture, race or language, is an unrealistic nostalgia which will only frustrate adherents of such a yearning at the end. It must be understood that the idea of a Reformed Church which was designed along cultural and linguistic lines remains archaic at best.

Talks concerning whether the church should unite or not has the ability to confuse the church in terms of its purpose. A true church always remains a united church, which jointly sees the many new challenges that God calls his church to focus on. A true and united church in present day South Africa (a young and fragile democracy) is one which refuses to be taken captive by sentiments and realises that it finds itself within a context plagued by unemployment, the HIV/AIDS pandemic, moral decay and poverty. What is more is that this church is a church in Africa. Great premium should thus be placed on the URCSA as being a church that has its roots in Africa and therefore needs to take that African context very seriously.

\section{REFERENCES}

Barth, K., 1956a, Church Dogmatics, vol. I/2, transl. G.T. Thomson \& H. Knight, T\&T Clark, Edinburgh.

Barth, K., 1962, Theology and Church, SCM Press, Great Britain.

Barth, K., 1981, The Christian Life: Church Dogmatics IV,4. Lecture fragments, Eerdmans, Grand Rapids.

Biggar, N., 1995, The Hastening that Waits: Karl Barth's ethics, Oxford University Press, New York.

Harinck, G., 2003, 'Tussen Barmen en Amsterdam' [Between Barmen and Amsterdam], Rede uitgesproken bij de aanvaarding van het ambt van bijzonder hoogleraar, Theologische Universiteit van de Gereformeerde Kerken, Amstelveen, Juni 06, 2003, p. 9.

Horn, N., 1984, "n Vergelykende studie van die Barmenverklaring en die van die konsepbelydenis van die N.G Sendingkerk', MA thesis, Universiteit van Port Elizabeth, Suid-Afrika.

Loff, C., 1998, 'Bevryding tot Eenwording: Die Nederduitse Gereformeerde Sendingkerk in Suid-Afrika 1881-1994', Doctoral dissertation, University of Kampen, The Netherlands.

Smit, D. \& Cloete, D. (eds.), 1984, A moment of truth: The confession of the Dutch Reformed Mission Church 1982, Eerdmans, Grand Rapids.

Smit, D., 2000, 'Versoening en Belhar?'[Reconsiliation and Belhar], Gereformeerd Theologisch Tijdschrift 4, 159-173.

Tshaka, R.S., 2007, ‘African you are on your own! - The need for African Reformed Christians to seriously engage their Africanity in their Reformed theological reflections', Scriptura 3, 533-548. 